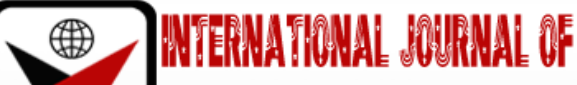

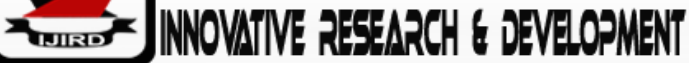

ISSN 2278-0211 (Online)

\section{China's Anti- Monopoly Law and Its Rules Relating to Foreign Entities: Reflecting on the Implications of Japan's Monopoly Case of Hard Drive Parts}

Yuxiang Qiao
Lecturer, School of Law, Anhui University of Finance \& Economics, China
Dong Yang
Lecturer, School of Business Administration,
Anhui University of Finance \& Economics, China
Jiagang Guo
Lecturer, School of Business Administration,
Anhui University of Finance \& Economics, China
Xingyu Zhu
Guoxin Ma
Teaching Assistant, School of Law, Anhui University of Finance \& Economics, China
Associate Professor, China Cooperative Research Institute,
Anhui University of Finance \& Economics, China

\begin{abstract}
:
China is building a foreign-related legal system. The theory of extraterritorial application in the field of anti-monopoly law has been studied for a long time, but China has not yet made relevant explanations regarding the extraterritorial application of Article 2 of the anti-monopoly law. From the judicial practice in the field of anti-monopoly law, it can be seen that there are many relevant cases of extraterritorial application, but few specifically raise the issue of extraterritorial jurisdiction and relevant interpretations of extraterritorial application. Therefore, through the research of various countries on the judgment process and analysis method of the Japanese HDD parts monopoly case, this article puts forward opinions on the problems existing in the practice of the anti-monopoly law applied outside the territory of China.
\end{abstract}

Keywords: China, Japan, anti-monopoly, law, foreign entity

\section{Introduction}

In 2018, the Japan JFTC (JFTC) issued an order for exclusion measures to Japan Clockwork, ordering it to rectify and prevent the recurrence of similar behaviors. In addition, a fine of approximately 10 million U.S. dollars, was issued to the Japanese Clockwork Company. This punishment is not only imposed by the JFTC, but the United States, Brazil, the United Kingdom, and Taiwan have also imposed corresponding penalties on the companies involved. In the process of hearing the case, the United States clearly used the 'effect theory', which is an extraterritorially applicable antitrust law, and the Federal District Court for the Eastern District of Michigan imposed a fine of 28.5 million U.S. dollars on the Japanese Clockwork Company[1].

The Conselho Administrativo de Defesa Econômica of Brazil (CADE) identified the behavior of the Japanese company as an international cartel and launched an investigation on the grounds that it may have an impact in Brazil[2]. In the United Kingdom, the Japanese company's liability for infringement damages is claimed in a civil class action[3]. The JFTC in Taiwan also investigated the case and imposed fines of approximately US\$4 million and US\$8 million on related companies[4].

Japan has always adopted a conservative attitude in the extraterritorial application of the Act on Prohibition of Private Monopolization and Maintenance of Fair Trade. When interpreting the extraterritorial application of domestic law, it is tried to avoid the American 'effect doctrine', but one would usually expand the interpretation of the jurisdiction theory of traditional international law. For example, when the Supreme Court of Japan tried a TV picture tube cartel case in 2017, it did not simply apply the Japanese anti-monopoly law on the grounds that the party's cartel behavior had an impact on the Japanese domestic market[5]. Instead, the Japanese parent company and foreign subsidiary are regarded as one body. Although the directly affected subsidiary is not in Japan, the CRT TV manufactured by the subsidiary is managed by the parent company, but the CRT is negotiated during the purchase process. The process is completed by the parent company. 
Therefore, it can be considered that it has also affected the Japanese parent company. In this way, it is legitimate to apply the Japanese Anti-Monopoly Law to regulate foreign companies.

The HDD Suspension Cartel case is another international cartel case after the JFTC case. This case did not enter the judicial review process, but was handled at the administrative stage. After the JFTC can reflect that the Supreme Court of Japan initially applied affirmative interpretations outside the domestic jurisdiction, what theories are now adopted by the Japanese Anti-monopoly Law Enforcement Agency as the basis for its jurisdiction. Comparing the judgments of the JFTC and the American courts in this case is in order to study with some depth the similarities and differences of the theoretical basis for the application of anti-monopoly law in the two countries, so as in order to provide an effective reference for the use of Anti-monopoly law outside the territory of China.

\section{Analysis of the Handling of Cases by JFTC}

\subsection{Company Profile}

The facts of the case are briefly described based on the report of the Japan JFTC. Nippon Clockwork Co., Ltd. is a company that manufactures and sells suspensions[6]. It guides the production and sales of its subsidiaries, and the subsidiaries produce and sell in accordance with the instructions of the parent company[7]. NAT, a subsidiary of Japan Clockwork Hong Kong, manufactures in accordance with the instructions and sells suspensions to hard drive manufacturers and sales companies. TDK Co., Ltd. sets a business policy for the production and sales of the hard disk head business and suspension of its subsidiary, and the subsidiary produces and sells the second head and suspension in accordance with the policy[8]. SAE Hong Kong is a subsidiary of TDK, which manufactures and sells magnetic heads and suspensions in accordance with TDK's business policy[9]. MPT Thailand is also a subsidiary of TDK and produces suspensions in accordance with TDK's guidelines. The legal representative of SAE and MPT is in charge of the head and suspension department of TDK[10].

\subsection{Introduction to the Implementation Process of Monopolistic Behavior}

From 2013 to May 2016, the Japanese hard disk market was monopolized by Toshiba in the production and sales market. Toshiba used suspensions produced by foreign countries (except NAT, SAE, and MTP) before March 2009. After April of the same year, it began to use SAE, Japanese spring, NAT, and MPT suspensions. TDK has established a synergistic relationship with Japan Clockwork through SAE's purchase of Japanese Spring's suspension and SAE's funding of NAT. TDK has also established a competitive relationship with the two companies of Japan Clockwork in the suspension sales market through a plan to obtain the decision right of MPT. Between 2007 and 2009, the two companies of Japan Clockwork and TDK met with sales leaders many times to discuss the use of maintaining sales prices against foreign suspension manufacturers. TDK communicates the policy of maintaining sales prices to SAE and MPT, and the latter two are implemented. The five companies exchanged suspension purchase customer quotes, sales prices, and price strategy information to fight against foreign low-priced suspension manufacturers in the Japanese hard disk market, thereby maintaining and ensuring their respective market shares and interests.

\subsection{Handling by the JFTC}

The JFTC believes that the consensual actions of the five companies violated the public interest and caused substantial restrictions on competition in the Japanese suspension sales market. Therefore, they belonged to the improper restrictions on trading prohibited by Article 2 paragraph 6 of the Japanese Anti-Monopoly Law and violated (The provisions of Article 3 of the Anti-Monopoly Law). For violators, the JFTC has taken measures to exclude restrictions and fines. Among them, two subsidiaries of TDK were exempted from penalties through the forgiveness/pardon system, while TDK was not fined for applying for the forgiveness/pardon system and another issue regarding its turnover.

\subsection{Analysis}

There are not many discussions on the case in Japanese academic circles. The main reason is that the case has not been heard by the court and has been dealt with at the stage of the JFTC. From the analysis of only scholars, it can be seen that this case is considered to be a case applicable outside the jurisdiction of Japan[11]. From the facts of the case, it can be understood that two of the five companies involved in the case are companies registered in Japan, and the other three are outside Japan. The monopolistic behavior is jointly implemented by the five companies. Although some of them are outside Japan, the place of action is Japan. From the judgment of the Supreme Court in the TV picture tube case, it can be known that the judging criteria for the extraterritorial application of the Japanese antitrust law: even if the cartel is reached abroad, the target of the cartel's transaction is a Japanese company and its competition is restricted, or When a price cartel damages the competitiveness of the Japanese market, it is deemed that the cartel is detrimental to Japan's free competition economic order, and Japanese law should be applied. However, it is not clear from the course of this case whether the cartel was reached abroad or domestically. TDK's price cartel's decision was made by TDK through several negotiations with Japan Clockwork and communicated to SAE and MPT. Although it can be speculated that the cartel was reached domestically, it does not seem to be the focus of the JFTC's implementation of extraterritorial application. The reason why this case is defined as an extraterritorially applicable case can be analyzed and concluded that the implementer of the result of the monopoly agreement is abroad, and this implementation has caused damage to the domestic enterprise. From the perspective of the company law, the finances of the parent company and the subsidiary are independent. If the parent company in Japan is solely responsible for the monopoly agreement, the parent company will have no turnover and cannot be punished. Therefore, it can be seen from the judgment of the Japanese Anti-Monopoly Law Enforcement Agency that 
monopoly behavior is a process. In the whole process, as long as you participate in it, it will become the object of regulation. According to the JFTC's description of this case 2(1), it can be known that TDK and Japan Spring are the parties to the monopoly agreement, and SAE, MPT, Japan Spring and NAT are the implementers of the monopoly agreement. The five companies that participated in the entire process of this monopolistic act are all subject to the jurisdiction of the Japanese Anti-Monopoly Law. Therefore, when levying fines, they are also levied on the basis of the turnover of the goods involved. If it claims extraterritorial application, companies that manufacture and sell suspensions outside of Japan will not be sanctioned[12]. In this case, the JFTC did not conduct an in-depth review of the basis for the extraterritorial application of Japan's anti-monopoly law.

Judging from Japan's past experience in the extraterritorial application of anti-monopoly laws, the 1990 Japan JFTC's 'Research Report on Foreign-related Issues of the Anti-monopoly Law' recognized the extraterritorial application of anti-monopoly laws based on the 'effect theory'. However, when trying cases in the courts, try to avoid applying the 'effect theory' and adopt the theory of the location of the demander to judge the case. Although the case did not clearly state which theory was adopted, judging from the facts of the case, the theory of the location of the demander can still be summarized. In the TV picture tube incident, the Supreme Court of Japan attributed the jurisdiction of the case to the theory of the location of the demander, but in fact it was not Japan's domestic companies that were affected but its foreign subsidiaries. Later, the practice of combining parent and subsidiary companies into one was criticized by Japanese scholars[13]. This case is the second case in the practice of Act on Prohibition of Private Monopolization and Maintenance of Fair Tradein which a fine was imposed on a company outside of Japan[14]. Compared with the TV picture tube incident, the direct impact of this case is suspension manufacturing and sales companies outside Japan, but the final effect is that competition in the suspension market in Japan is harmed. Therefore, in addition to the Japanese anti-monopoly agency in this case, anti-monopoly agencies in other countries have also responded. Take the United States as an example to compare with Japan, study the differences, and finally make suggestions on the extraterritorial application of China's antimonopoly law.

\section{Analysis of the Handling of Cases in the United States [15]}

\subsection{Brief Introduction of the Facts of the Case and the Content of the Judgment}

The United States, like Japan, regulates the monopolistic behavior of the above five companies. Unlike Japan, the United States did not abruptly stop at the stage of anti-monopoly agencies, but went to judicial proceedings, and it was a lawsuit filed by civil subjects. The plaintiffs included residents of New York and companies in Washington, DC. The court in Southern New York, the United States, heard the case. In addition, the defendants also include Hutchinson Technology Inc and Headway Technologies, Inc., wholly-owned subsidiaries of TDK in the U.S.; NHK International Corporation, a U.S. subsidiary of Japan Clockwork; and NHK Spring Precision (Guangzhou) Co., Ltd., a subsidiary of NAT in Guangdong, China. Peripheral (Dong Guan) Co., Ltd., NAT Peripheral (HK) Co., Ltd.; the defendant was eventually sentenced to criminal punishment. The plaintiff believes that the defendant's price collusion on HDD suspension violated the Sherman Antitrust Act of Title 15 of the United States Code. In the process of hearing the case, the US court first elaborated on the issue of jurisdiction. In paragraph 14 of the document, it is stated that the court has jurisdiction over the subject matter of the litigation; paragraph 15 indicates that the place where the incident occurred is within the jurisdiction of the court and provides the basis for territorial jurisdiction; paragraph 16 states that the defendant controls the subsidiary directly or through ownership. The scope of business includes This state and the entire United States have a direct, substantial and reasonably foreseeable impact on American interstate trade. The reason is that goods are sold in American interstate trade (paragraph 18). From the sales path, it can be seen that the goods are in the United States. Manufactured abroad and imported into the United States (paragraph 19), so this case is a case applicable outside the United States. In addition, it is clear that the relevant product is a hard drive suspension, and the relevant geographic market is all parts of the United States, and pointed out that the defendant's global market share is $90 \%$, which further illustrates the severity of the impact brought by the cartel. Monopolistic behavior includes fixing prices and dividing market shares through conspiracy (paragraph 46), thereby restricting new opportunities for entry into the commodity market (paragraph 53).

In the judgment process, Professor Jeffrey K. MacKie-Mason and Professor Arthur W. Burks of the University of Michigan were cited in the Microsoft monopoly case on the judgment standard of consumer damage behavior, and the economic theory demonstrated that the cost is passed on to consumers. The damage caused (paragraph 74) was used to determine that the monopolistic behavior in this case was direct and predictable. From the market share of the goods involved, it can be found that the effect of the monopoly is significant.

\subsection{Analysis}

It can be seen from the US court's handling of the case that the jurisdiction of this case is first explained, based on not only the territorial principle, the personal principle, but also the effect theory. In the process of analyzing and elaborating the effect theory, the traditional judgment standard 'direct, substantial, and reasonably foreseeable' was used, which was introduced into the case separately, and each element was judged separately. In the field of competition law, the United States was the first country to propose extraterritorial application of anti-monopoly law. After the effect theory was first proposed in the aluminum product case in 1945, it was opposed by various countries, believing that the U.S. approach violated the basic principles of international law[16]. It can be found from this case that the parties involved in the case are all legal persons outside the United States, and the judgment clarified a settling law applicable to the behavior of foreigners in a foreign country, if it brings the effects of the state's prohibition in the country. At that time, the country can hold the foreigner accountable. 
At that time, this theory overturned the basic principles of jurisdiction in traditional international law, surpassed the national sovereignty based on national borders, and clashed with the principle of national sovereignty. From the framework of traditional international law, the application of domestic law is established within the geographic scope of the country. Crimes that are mainly constrained within the territory of the country, regardless of whether they are nationals or foreigners, are subject to legal sanctions. The establishment of the territorial principle is mainly to reflect the independence of national sovereignty, that is, one's own domestic affairs are managed by one's own country. With the development of navigation technology, the scope of human activities has exceeded the limits of the country's borders. As the scope of activities increases, the scope of application of domestic law is also facing challenges. In the Lotus incident in 1926, the International Court of Justice (ICJ) broke through the limits of domestic jurisdiction of criminal law[17]. In the past, such extraterritorial application of domestic law was considered to violate the strict territorial principle of international law[18]. Therefore, at that time, various countries opposed such domestic extraterritorial application through diplomatic protests[19], submission of opinions to US courts[20], and confrontational legislation[21]. The United States has also taken corresponding measures in response to the opposition of various countries. This is mainly reflected in making the law more transparent in the process of application. In 1982, the Foreign Trade Antitrust Improvements Act (FTAIA) was promulgated, which established the application benchmark of the effect theory-'direct, substantial and reasonably foreseeable effects.' In 2017, ANTITRUST GUIDELINES FOR INTERNATIONAL ENFORCEMENT AND COOPERATION was promulgated to clarify the limits of the U.S. Sherman Law. The bill mainly uses cases to explain the judgment criteria applicable outside the US jurisdiction.

\section{Implications for China}

With the development of the global economy, various countries have more or less accepted the practice applied outside the United States Sherman's law. Some countries have not adopted the United States' effect theory due to the basic principles of traditional international law, but have expanded the interpretation of the territorial principle.Such as: the EU's principle of place of implementation; there are also expanded interpretations of the principle of belonging, such as the EU's theory of economic integration (supplier), and the theory of Japanese demander integration. Some countries directly adopt the effect theory of the United States, such as Article 2 of the Chinese Anti-Monopoly Law[22] and Article 185, paragraph 2 of the Gesetzgegen Wettbewerbsbeschränkungen (GWB) [23]. It can be seen that after a long period of international practice, the extraterritorial application of the anti-monopoly law has become a way of claiming jurisdiction recognized by all countries.

Through the handling of the JFTC and the US Interstate Court in this case, it can be seen that Japan did not provide a theoretical basis for judgment and a detailed judgment process in the process of handling the case. On the contrary, in accordance with the rules applicable outside the Sherman law, the US courts separately discussed 'direct, substantial, and reasonably foreseeable', thereby claiming its jurisdiction. In addition, when claiming jurisdiction, different parties can claim different legal grounds. For example, those who are in the United States can claim territoriality, and those who are not in the United States can claim the principle of humanism or effect.

After the implementation of China's anti-monopoly law in 2008, the anti-monopoly authorities have dealt with many cases of extraterritorial application, such as the Coca-Cola acquisition of Huiyuan, the Japanese auto parts company cartel, and the prohibition of Maersk, Mediterranean Shipping, and CMA CGM from establishing network centers. The extraterritorial provisions of Article 2 have not been explained in detail through the practice of the court. In Huawei v. American Interactive Digital (IDC), the wording of 'direct, significant, substantial, and reasonably foreseeable impact' appeared[24]. During the trial of the case, the issue of the extraterritorial effect of China's anti-monopoly law became the focus of debate. The interpretation given by the presiding judge Haitang Xiao of Shenzhen Sino-French is that Article 2 of China's Anti-Monopoly Law clearly stipulates the provisions applicable outside the territory, and in the case, IDC's monopolistic behavior has had a significant impact on the production and export of related products in China. Substantial and reasonably foreseeable impact, so the Chinese anti-monopoly law can be applied. It can be seen that the judges in China have such awareness in the process of hearing cases. However, China's does not have a relatively clear interpretation rule or application manual for Article 2 of the Anti-Monopoly Law, which is different from the US FTAIA.

China is strengthening the construction of a foreign-related legal system. In this process, the author believes that the anti-monopoly law that currently applies the most cases outside the territory should be the first to build the system. The main reasons are: 1. China's has proposed the One Belt One Road policy, which has increased the opportunities for Chinese enterprises to enter and exit the international market. Only clear and transparent laws can ensure that enterprises compete in a fair and just economic environment; 2. China's long-arm jurisdiction over European and American laws We have suffered a loss and promulgated anti-foreign sanctions laws to counter foreign countries' unreasonable and unreasonable extraterritorial application. On the contrary, if China's extraterritorial application is not transparent and there is no corresponding fixed express provision, it is very likely to suffer Countermeasures in foreign countries; 3 . Interpretation of the rules applicable outside the antitrust law can improve China's domestic fair and transparent competition environment, thereby attracting more foreign investors.

It is worth noting that in the process of China's interpretation of extraterritorial application, there is no need to interpret important, substantive, and reasonably foreseeable rules too rigidly. For example, more than a certain amount is significant, and such an explanation is not conducive to the protection of China's market order. The main reason is that the author believes that China is still in the period of market economy development, and some foreign goods or services are less exposed to China or have not yet emerged. It is obviously unreasonable to judge the impact on the market simply by the amount. Therefore, a comprehensive judgment must be made. 


\section{References}

i. Japanese Manufacturer Agrees to Plead Guilty to Fixing Prices for Suspension Assemblies Used in Hard Disk Drives

ii. https://www.justice.gov/opa/pr/japanese-manufacturer-agrees-plead-guilty-fixing-prices-suspensionassemblies-used-hard-disk

iii. CCADE's General Superintendence probes cartel in the global market for hard disk components

iv. http://en.cade.gov.br/cades-general-superintendence-probes-cartel-in-the-global-market-for-hard-diskcomponents-1

v. Amended pursuant to order of Mr. Justice Coval made April 9, 2021 pursuant to Supreme Court Civil Rule 6-2(7\}. P22

vi. https://www.cfmlawyers.ca/wp-content/uploads/2021/05/FILED-Amended-Notice-of-Civil-Claim-13-Apr2021-00805722xB33C8.pdf

vii. Company name : Copyright NHK SPRING Co.,Ltd. Company Address: Hukuura3-10, Kanazawaku, Yokohamashi, Kanagawaken, Japan.

viii. Company name: NAT Peripheral (H. K.) Co., Ltd. Company Address: Suite Nos. 15B-17, 9th Floor, Tower 3, China Hong Kong City, 33. Canton Road, T.S.T., Kowloon, Hong Kong

ix. Company Address: TDK Corporation Company Address : 2-5-1 Nihonbashi, Chuo-ku, Tokyo

x. Company Address: SAE Magnetics (H.K.) Ltd. Company Address : 6 Science Park East Ave, Hong Kong Science Park, Shatin, N.T. Hong Kong

xi. Company Address: Magnecomp Precision Technology Public Co., Ltd. 地址 : 162 Moo 5, Phaholyothin Road, T.Lamsai A. Wangnoi, Ayutthaya 13170, Thailand https://www.jftc.go.jp/houdou/pressrelease/h30/feb/180209_1_files/201802beppyou.pdf

xii. Case 1:19-cv-07428 Document $1 \quad$ Filed 08/08/19https://www.hfajustice.com/wpcontent/uploads/2019/08/2019.08.08-FILED-Complaint-002.pdf

xiii. U. S. v. A1uminum Co. of America, 148F. 2d. 416

xiv. 'The Case of the S.S. 'Lotus". PCIJ Series A, No. 10.[

xv. GesetzgegenWettbewerbsbeschränkungen (GWB) $§ 185$ (2) Die Vorschriften des Erstenbis DrittenTeils dieses Gesetzessind auf alle Wettbewerbsbeschränkungenanzuwenden, die sichim Geltungsbereich dieses Gesetzesauswirken, auchwennsieaußerhalb des Geltungsbereichs dieses Gesetzesveran lasstwerden.

xvi. 2013）粤高法民三终字第 306 号 51页。

xvii. Chang, Eun K., "Expanding Definition of Monopoly Leveraging" University of Miami Business Law Review, Vol17. No.325. (July 2009)

Clarke-Smith, Jennifer M., The Development of the Monopolistic Leverage Theory and its Appropriate Role in Antitrust Law, 52 Cath U L Rev ,(2002). Dolan, William F., Developments in Private Antitrust Enforcement in 2000, PLI/CORP, No.1252 (2001). 